\title{
ANALISIS PENURUNAN TIMBUNAN TANAH SILT PADA PROYEK JALAN RUAS GIRIWOYO-DUWET WONOGIRI
}

\author{
Agung Prakoso"), Muhammad Mukhlisin ${ }^{1, *)}$, Pentardi Rahardjo ${ }^{1)}$, Junaidi ${ }^{1)}$ \\ ${ }^{1)}$ Jurusan Teknik Sipil Politeknik Negeri Semarang \\ Jl. Prof H. Sudarto, S.H. Tembalang Semarang 50275 \\ ${ }^{*}$ Email: mmukhlisin@gmail.com
}

\begin{abstract}
The foundation layers of road construction in general have many problems of land subsidence. Land subsidence does not occur only on the ground or the original soil. Decrease of soil may also occur on pile or soil. Less than optimal density of the soil or the choice of unsuitable heap material may be the cause of the land subsidence in the embankment. Land subsidence also occurred in the National Road Development Project Segment Giriwoyo-Duwet, Wonogiri, Central Java, Indonesia, causing a decrease in road elevation from planned elevations. Decreasing this elevation can cause the standards of the cleverness and comfort of the road not being met. This study explains the results of the analysis of the large decrease in soil that occurred. The analysis is done by two methods. The method is done by theoretical calculation and by analysis using plaxis software. The results of the analysis show that the characteristics of soil used as soil pile material is silt soil with high and soft plasticity characteristics. The analysis also illustrates the factors of land degradation due to poor soil characteristics, carrying capacity and soil density less than standard and weather factors. The magnitude of the decline that occurred showed a decrease of 3-7 cm from the observation on the location, $1,1 \mathrm{~cm}$ from the results of plaxis software analysis and 1,7 cm from theoretical calculations.
\end{abstract}

Kata kunci : road subsidence, soil silt land, plaxis analysis.

\section{PENDAHULUAN}

Pembangunan infrastruktur yang masif diharapkan oleh pemerintah sebagai pemacu pertumbuhan ekonomi. Pelaksanaan pembangunan yang dilakukan sering mengalami kendala dalam proses pembangunannya, salah satunya adalah penurunan tanah. Penurunan tanah adalah salah satu masalah yang sering dijumpai dalam proses kontruksi. Tanah dasar (subgrade) dan timbunan dalam struktur jalan merupakan bagian yang sangat penting, karena bagian ini akan memikul beban struktur lapis keras dan beban lalu lintas. Tanah dasar dan timbunan pada struktur kontruksi jalan umumnya menggunakan tanah setempat, namun ada kalanya kondisi tanah dasar tersebut tidak menguntungkan, misalnya berupa tanah lunak. Tanah dasar dan timbunan berupa tanah lunak akan berada pada kondisi kaut geser yang terburuk, sehingga kekuatan daya dukungnya menjadi sangat rendah. Penurunan (settlement) yang terletak pada tanah berbutir halus yang jenuh dapat dibagi menjadi 3 komponen, yaitu penurunan segera (immediate settlement), 
penurunan konsolidasi primer, penurunan konsolidasi sekunder.

Kasus penurunan tanah terjadi pada tanah silt pada timbunan proyek pembangunan jalan nasional Ruas Giriwoyo-Duwet, Wonogiri, Jawa Tengah. Penurunan terjadi saat proses pembangunan masih berlangsung. Tanah timbunan di beberapa STA mengalami penurunan setelah diberikan lapis pondasi agregat B (LPB)/ subbase dan lapis pondasi agregat A (LPA)/ base bahkan ketika telah diberikan lapis perkerasan aspal. Penurunan terjadi umunya sekitar 3-7 $\mathrm{cm}$.

Kasus kedua penurunan tanah lempung pada tanah dasar Tol SoloKertosono Ruas ColomaduKaranganyar, Jawa Tengah yang mengalami penurunan sebesar $8-15 \mathrm{~cm}$ pada STA $8+000-$ STA $12+000$ membuat elevasi jalan mengalami penurunan dari elevasi rencana. Penurunan terjadi pada ruas yang telah selesai pembangunannya pada 2015. Tanah mengalami penurunan akibat proses konsolidasi yang terjadi ketika tanah menahan beban lapis perkerasan dan beban lalu lintas proyek.

Kasus ketiga yaitu penurunan tanah lempung berpasir dan lanau berlempung pada tanah timbunan runway Bandar Udara Kuala Namu, Sumatra Utara. Tanah timbunan runway mengalami penurunan akibat konsolidasi tanah ketika konsolidasi tanah mencapai $90 \%$ sebesar 1,82 meter. Penurunan yang terjadi akan membuat kelandaian runway tidak sesuai standar yang ditentukan sehingga dapat membahayakan lalu lintas landing dan take off pesawat.

Kasus keempat adalah penurunan tanah dasar pada Kawasan Industri Rungkut dan Kawasan Waru, Surabaya, Jawa Timur. Penurunan terjadi akibat hilangin air tanah yang menyebabkan tanah mengalami pemadatan yang berakibat terjadinya penurunan sebesar $1,21 \mathrm{~cm} /$ tahun Penurunan yang terjadi dapat mempengaruhi kondisi pondasi bangunan yang bertumpu pada tanah yang mengalami penurunan.

Pada penelitian sebelumnya yang dilakukan Budi dkk (2003), mengevaluasi penurunan tanah liat pada daerah Industri Margomulyo, Surabaya dengan metode sub-layer dan metode one-point. Hasil dari evaluasi yang dilakukan menunjukkan penurunan dengan metode sub-layer lebih besar yaitu sebesar $6,81 \mathrm{~cm}$ dibandingkan dengan metode onepoint sebesar $5,64 \mathrm{~cm}$.

Pasaribu dan Iskandar (2012) melakukan analisis penurunan tanah dan waktu konsolidasi pada tanah timbunan berjenis tanah lunak pada runway Bandara Medan Baru. Metode yang digunakan untuk menganalisa penurunan adalah metode Hansbro. Hasil yang diperoleh adalah waktu yang dibutuhkan untuk mencapai konsolidasi $90 \%$ selama 6,82 tahun dan terjadi penurunan sebesar 1,82 meter.

Penelitian yang dilakukan Widianti (2012) memaparkan analisis pengaruh jumlah lapisan dan spasi perkuatan geosintetik terhadap kuat dukung dan penurunan tanah lempung 
lunak di Wates, Kulon Progo, Daerah Istimewa Yogyakarta. Metode yang digunakan dengan melakukan uji loading pada tanah yang dilakukan perbaikan dengan geosintetik yang dibuat model box ukuran 120x120x100 $\mathrm{cm}^{2}$. Penurunan tanah berkurang setiap penambahan lapis geosintetik. Tanah dengan 1 lapis geosintetik mengalami pengurangan penurunan sebesar $40 \%$, 2 lapis geosintektik mengalami pengurangan penurunan sebesar $60 \%$ dan dengan 3 lapis geosintetik mengalami pengurangan penurunan sebesar $70 \%$.

Zahara (2008) menganalisa penurunan konsolidasi tanah lempung berpasir dan lanau berlempung pada proyek Bandar Udara Kuala Namu dengan perbandingan perhitungan penurunan tanah menggunakan teori konsolidasi Terzaghi dengan program plaxis. Hasilnya perhitungan penurunan tanah dengan teori Terzaghi didapat angka besar penurunan sebesar 0,739 m selama 1398 hari lebih besar dari hasil metode elemen hingga dengan program plaxis sebesar 0,701 m selama 1080 hari.

Fandisnata (2014) melakukan studi perbandingan kapasitas dukung embankment dengan perkuatan cerucuk tegak dan cerucuk miring kayu galam pada tanah lunak di ruas Tol Samarinda-Balikpapan, Kalimantan Timur. Studi perbandingan menggunakan model numerik 2D (Plaxis 2D) untuk mempelajari perilaku embankment. Hasil analisa menggambarkan perkuatan tanah dengan cerucuk tegak mengalami penurunan sebesar $1,8 \mathrm{~m}$ dan perkuatan dengan cerucuk mirik mengalami penurunan sebesar 1,73 m. Penelitian yang dilakukan Nawir dkk (2012) memaparkan analisa penurunan tanah timbunan berjenis tanah lunak dengan perbaikan drainase vertikal di Bontang, Kalimantan Timur yang dilakukan dengan perbandingan perhitungan penurunan tanah menggunakan teori konsolidasi Terzaghi, metode elemen hingga (FEM) dan prosedur Asaoka. Hasil analisa menunjungkan angka penurunan berdasarkan analisis perhitungan Terzaghi sebesar 1030 mm dan berdasarkan FEM sebesar 712 $\mathrm{mm}$ sementara itu analisa dengan menggunakan prosedur Asaoka menunjukkan penurunan sebesar 658 $\mathrm{mm}$.

Daryaei dan Eslami (2017) melakukan evaluasi penurunan karena pemadatan yang eksplosif pada kondisi tanah berpasir jenuh. Analisis ini dilakukan dengan menggunakan software Plaxis 3D. Hasil dari analisis menggunakan Plaxis 3D dikalibrasi dan dibandingkan dengan persamaan empiris dan nilai penurunan yang langsung diukur di lokasi, sehingga dinyatakan analisis numerik dengan menggunakan Plaxis 3D dapat diimplementasikan secara efektif untuk mengevaluasi penurunan dan karakteristik tanah.

Dari beberapa kasus dilapangan dan informasi dari penelitian yang sudah dilakukan, seperti analisis terhadap tanah lunak yang dilakukan Pasaribu dan Iskandar (2012), Fandisnata (2014), Nawir (2012), analisis tanah lempung oleh Widianti 
(2012), Zahara (2008), analisis tanah liat oleh Budi dkk (2003) dan Tanah berpasir jenuh oleh Daryaei dan Eslami (2017). penelitian ini mencoba untuk melakukan analisis terhadap penurunan segera (immediate settlement) tanah timbunan berjenis silt pada proyek pembangunan jalan nasional Ruas Giriwoyo-Duwet, Wonogiri, Jawa Tengah dengan membandingkan hasil analisa perhitungan secara teoritis, hasil analisa software Plaxis dengan data uji sepuluh sampel tanah dan pengamatan langsung di lokasi. Tujuan dari analisis ini untuk mendapatkan gambaran besar penurunan yang terjadi pada tanah timbunan akibat penurunan segera dari hasil analisis tiga metode yang dilakukan.

\section{METODE PENELITIAN} Lokasi dan Waktu Penelitian

Lokasi pengambilan data tanah dilakukan pada pembangunan jalan nasional Ruas Giriwoyo-Duwet, Wonogiri, Jawa Tengah, ditunjukkan pada Gambar 1.

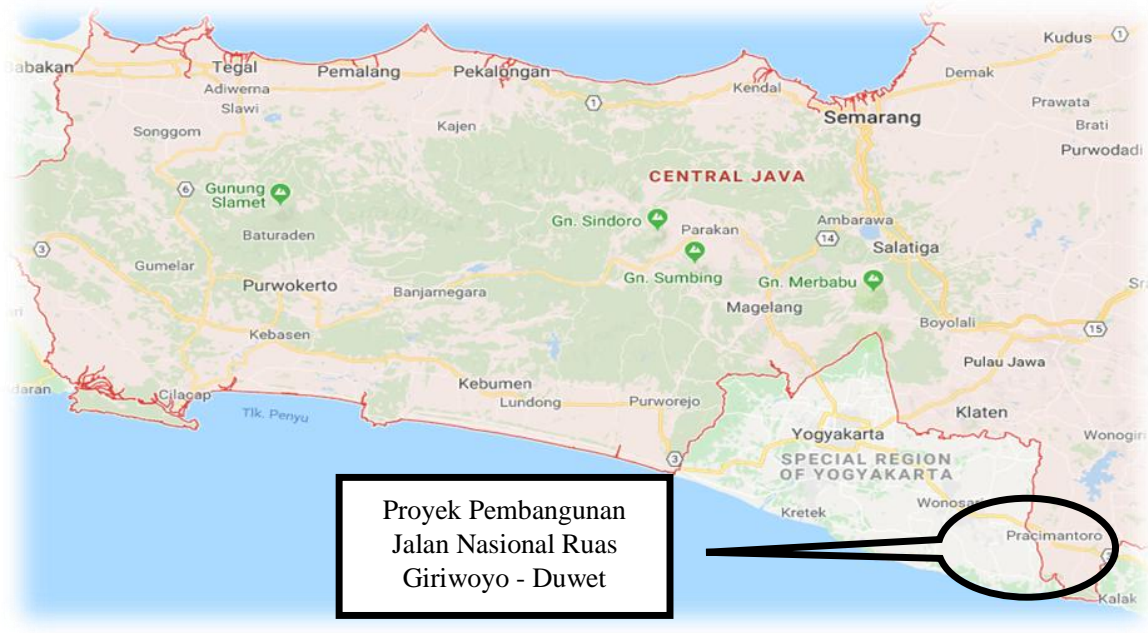

Gambar 1. Peta Provinsi Jawa Tengah dan D.I. Yogyakarta

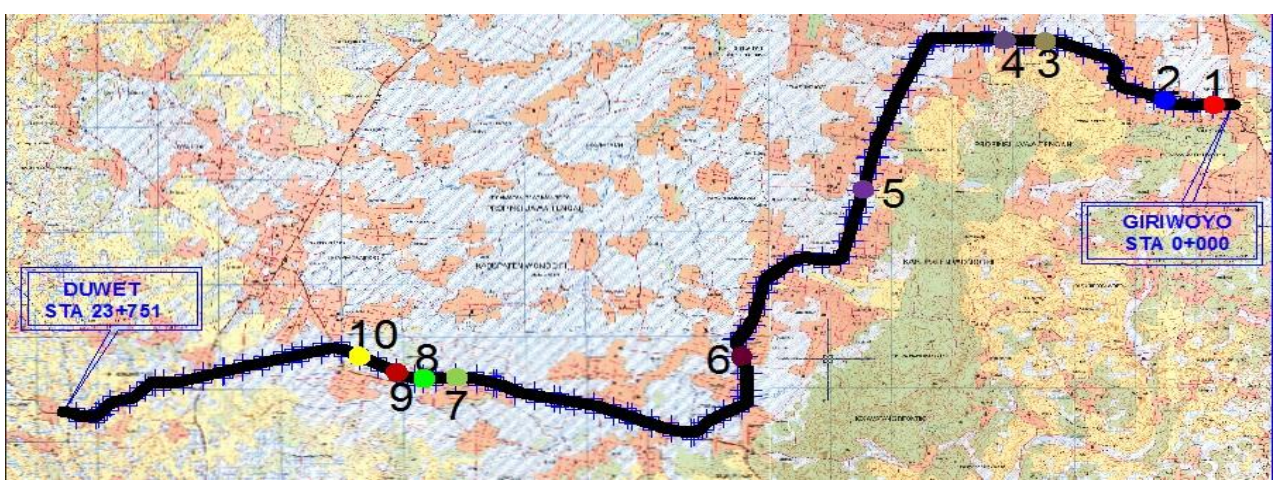

Gambar 2. Peta Lokasi Proyek Pembangunan Jalan Lintas Selatan GiriwoyoDuwet

(Sumber : PPK Batas Jatim-Giriwoyo-Duwet, 2015) 
Proyek pembangunan jalan nasional Ruas Giriwoyo-Duwet, Wonogiri, Jawa Tengah memiliki trase sepanjang 23,751 Km. Proses pembangunan jalan dilakukan dengan melakukan penyelidikan tanah sebanyak 10 titik sampel tanah sebagai bahan perencanaan dan pembangunan jalan.

\section{Teori Penurunan Tanah}

\section{Penurunan Segera Berdasarkan}

\section{Teori Timonshenko dan Goodier}

Penurunan segera atau penurunan elastis adalah penurunan yang dihasilkan oleh distorsi massa tanah yang tertekan, dan terjadi pada volume konstan. Penurunan pada tanah-tanah berbutir kasar dan tanah-tanah berbutir hasil tidak jenuh termasuk tipe penurunan segera, karena penurunan terjadi segera setelah terjadi penerapan beban (Aridini, 2017).

Rumus penurunan segera dikembangkan berdasarkan teori (Timonshenko dan Goodier, 1951) sebagai berikut:

$S i=\frac{q B}{E s}\left[\left(1-\mu^{2}\right) I p\right.$

Dimana :

$\mathrm{Si} \quad=$ Penurunan Segera

$\mathrm{q}_{\mathrm{n}} \quad=$ Tekanan pada dasar pondasi netto

B = Lebar Pondasi

$\mu \quad=$ Angka Poisson

Es = Modulus Elastisitas Tanah

Ip $\quad=$ Faktor Pengaruh Yang Tergantung Dari Kontak Pondasi Dan Kekauan Pondasi
Besarnya tegangan kontak berubah akibat bertambah dalamnya tinjauan, sehingga menjadi:

$A \sigma=\frac{q o \cdot B \cdot L}{(B+z)(L+z)}$

Sehingga,

$S i=\frac{A \sigma B}{E s}\left(1-\mu^{2}\right) I p$

Dimana:

$A \sigma=$ Penambahan tegangan rata-rata sesuai kedalaman tinjauan $\left(\mathrm{t} / \mathrm{m}^{2}\right)$

$\mathrm{q}_{\mathrm{o}}=$ beban pada pondasi

$\mathrm{Z} \quad=$ penambahan lebar daerah tekan pada pondasi sesuai kedalaman tinjauan.

Analisis dilakukan dengan dua permodelan pembebanan yaitu penurunan akibat beban yang di terima tanah dari lapis subbase dan beban yang diterima tanah dari lapis subbase ditambah dengan beban maksimum kendaraan. Parameter tanah yang digunakan untuk perhitungan adalah parameter tanah timbunan yang ditunjukkan pada Tabel 1.

\section{Penurunan Segera Berdasarkan}

Permodelan Plaxis

Plaxis (Finite Elemen Code for Soil and Rock Analyses) adalah sebuah paket program yang disusun berdasarkan metode elemen hingga yang telah dikembangkan secara khusus untuk melakukan analisis deformasi dan stabilitas dalam bidang rekayasa geoteknik.

Analisais menggunakan plaxis diawali proses dengan plaxis input lalu plaxis calculation selanjutnya didapat hasil analisis dalam plaxis output dan plaxis curve. Analisis plaxis dilakukan dengan beberapa simulasi keadaan 
tanah dari parameter hasil uji 10 sampel tanah yang ada. Analisis dilakukan dengan dua macam permodelan beban yaitu dengan beban lapis pondasi agregat $\mathrm{B}$ dan dengan ditambah beban maksimum kendaraan. Analisis dilakukan pada objek pondasi jalan dengan penampang dan ukuran yang ditunjukkan pada Gambar 3.

Pada Gambar 3 menunjukkan objek analisis mempunyai susunan lapis yaitu tanah asli/ tanah dasar sedalam $3 \mathrm{~m}$ lalu dilakukan timbunan setinggi $60 \mathrm{~cm}$ dan lapis pondasi agregat B (LPB) setinggi $20 \mathrm{~cm}$. Analisis pada permodelan plaxis juga dilakukan skenario dengan perkuatan geotekstile antara lapis tanah asli dengan tanah timbunan dan antara lapis tanah timbunan dengan lapis pondasi agregat $\mathrm{B}$, sementara itu muka air tanah berada pada 2,2 $\mathrm{m}$ di bawah permukaan tanah asli. Analisis dilakukan dengan menggunakan parameter tetap tanah asli dilokasi dan parameter LPB, seperti pada Tabel 2.

Tabel 1. Parameter Perhitungan Teoritis

\begin{tabular}{ccc}
\hline Parameter Tanah & Tanah Timbunan (ex STA 3+795) & Unit \\
\hline Material Model & $\mathrm{MC}$ & - \\
Type of Behaviour & Undrained & - \\
Dry Weight & 10,8 & $\mathrm{KN} / \mathrm{m}^{3}$ \\
Wet Weight & 15,8 & $\mathrm{KN} / \mathrm{m}^{3}$ \\
Permeability X-dir & $1.10^{-3}$ & $\mathrm{~m} / \mathrm{d}$ \\
Permeability Y-dir & $1.10^{-3}$ & $\mathrm{~m} / \mathrm{d}$ \\
Young Modulus & 9807 & $\mathrm{KN} / \mathrm{m}^{2}$ \\
Poisson Ratio & 0,30 & 0,30 \\
Cohesion & 7,72 & $\mathrm{KN} / \mathrm{m}^{2}$ \\
Friction Ratio & 9,91 & $\circ$ \\
Dilatancy Angle & 0 & $\circ$ \\
Qn beban subbase & 32,10 & $\mathrm{KN} / \mathrm{m}^{2}$ \\
Qn beban subbase + Beban & 228,100 & $\mathrm{KN} / \mathrm{m}^{2}$ \\
Kendaraan & & \\
Lebar Pondasi & 15 & $\mathrm{~m}$ \\
Ip & 0,840 & - \\
\hline
\end{tabular}

(Sumber : PPK Batas Jatim-Giriwoyo-Duwet. 2017)

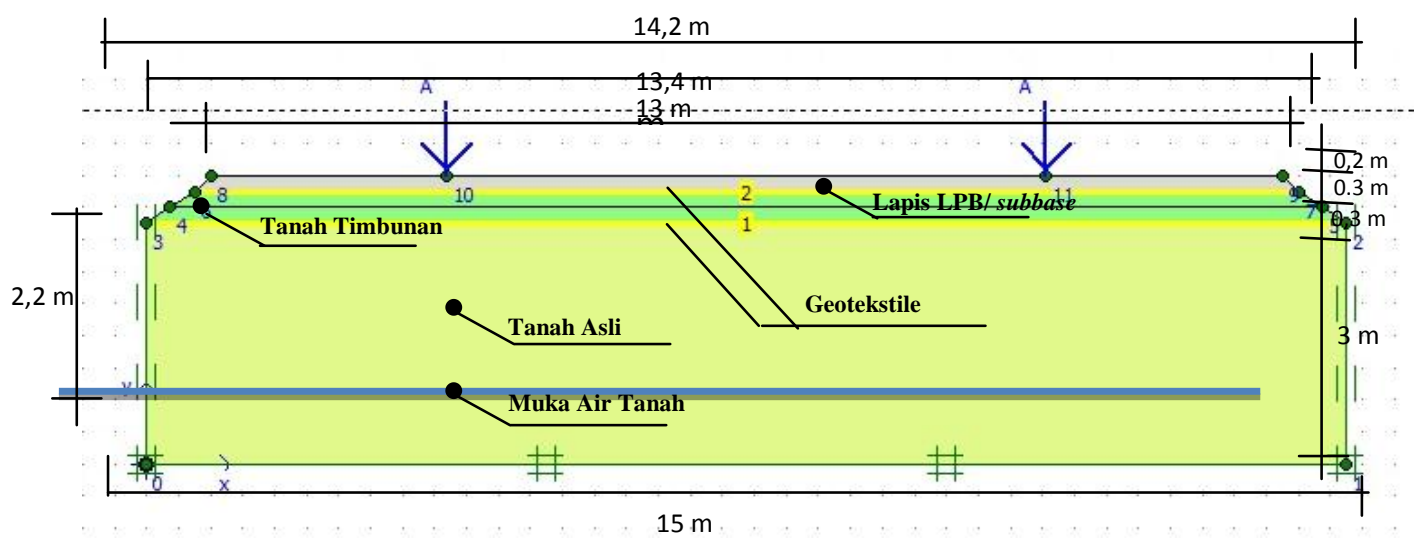

Gambar 3. Potongan Melintang Badan Jalan 
Tabel 2. Parameter Tanah Asli dan LPB

\begin{tabular}{cccc}
\hline Parameter Tanah & Tanah Asli (STA 3+795) & LPB & Unit \\
\hline Material Model & MC & MC & - \\
Type of Behaviour & Undrained & drained & - \\
Dry Weight & 10,4 & 21,40 & $\mathrm{KN} / \mathrm{m}^{3}$ \\
Wet Weight & 15,8 & 22,28 & $\mathrm{KN} / \mathrm{m}^{3}$ \\
Permeability X-dir & $1.10^{-3}$ & 1,0 & $\mathrm{~m} / \mathrm{d}$ \\
Permeability Y-dir & $1.10^{-3}$ & 1,0 & $\mathrm{~m} / \mathrm{d}$ \\
Young Modulus & 9807 & 9807 & $\mathrm{KN} / \mathrm{m}^{2}$ \\
Poisson Ratio & 0,30 & 0,30 & 0,30 \\
Cohesion & 7,72 & 39,23 & $\mathrm{KN} / \mathrm{m}^{2}$ \\
Friction Ratio & 9,91 & 15,35 & $\circ$ \\
Dilatancy Angle & 0 & 0 & $\circ$ \\
\hline
\end{tabular}

(Sumber : PPK Batas Jatim-Giriwoyo-Duwet, 2017)

Parameter tanah timbunan dilakukan dengan melakukan tiga skenario parameter tanah dengan material model $\mathrm{MC}$ dan type of behaviour tanah adalah undrained. Skenario I terdapat lima kasus parameter tanah dari sampel tanah 1,3,4,5 dan 8 yang berada pada titiktitik kritis tanah silt. Parameter tanah

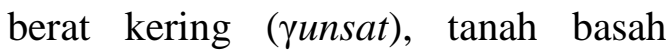
( $\gamma$ sat), kohesi (C), dan sudut geser $(\varphi)$ menggunakan hasil uji sampel 1,3,4,5 dan 8 dan parameter permeability, modulus elastisitas (E) dan angka poison (v) menggunakan standarisasi parameter tanah Bowles. Skenario II terdapat 6 kasus parameter tanah dengan parameter tanah berat kering ( unsat), tanah basah ( $\gamma$ sat) dari hasil sampel uji 2 dan parameter permeability, modulus elastisitas (E) dan angka poison ( $v$ ) menggunakan standarisasi parameter tanah Bowles. Kasus A pada skenario 2 menggunakan nilai kohesi (C) rata-rata dari 10 sampel uji dan sudut geser $(\varphi)$ menggunakan nilai terendah, rata-rata dan terbesar dari 10 hasil uji sampel tanah yang ada dan kasus B pada skenario 2 menggunakan nilai kohesi (C) nilai terendah, rata-rata dan terbesar dari 10 hasil uji sampel tanah yang ada dan sudut geser $(\varphi)$ menggunakan rata-rata dari 10 sampel uji.

Skenario III terdapat 6 kasus parameter tanah dengan parameter tanah berat kering ( $\gamma$ unsat), tanah basah ( $\gamma$ sat) dari hasil rata-rata 10 sampel uji tanah dan parameter permeability, modulus elastisitas (E) dan angka poison ( $v$ ) menggunakan standarisasi parameter tanah Bowles. Kasus A pada skenario 2 menggunakan nilai kohesi (C) rata-rata dari 10 sampel uji dan sudut geser $(\varphi)$ menggunakan nilai terendah, rata-rata dan terbesar dari 10 hasil uji sampel tanah yang ada dan kasus B pada skenario 2 menggunakan nilai kohesi (C) nilai terendah, rata-rata dan terbesar dari 10 hasil uji sampel tanah yang ada dan sudut geser $(\varphi)$ menggunakan rata-rata dari 10 sampel uji, seperti yang ditunjukkan pada Tabel 3. 
Tabel 3. Parameter Tanah Timbunan

\begin{tabular}{|c|c|c|c|c|c|c|c|c|c|}
\hline Skenario & Kasus & $\begin{array}{c}\text { runsat } \\
\left(\mathrm{KN} / \mathrm{m}^{3}\right)\end{array}$ & $\begin{array}{c}\gamma s a t \\
\left(\mathrm{KN} / \mathrm{m}^{3}\right)\end{array}$ & $\begin{array}{c}\text { Kx-dir } \\
(\mathrm{m} / \mathrm{d})\end{array}$ & $\begin{array}{l}\text { Ky-dir } \\
(\mathrm{m} / \mathrm{d})\end{array}$ & $\begin{array}{c}\mathrm{E} \\
\left(\mathrm{KN} / \mathrm{m}^{2}\right)\end{array}$ & $v$ & $\begin{array}{c}\mathrm{C} \\
\left(\mathrm{KN} / \mathrm{m}^{2}\right)\end{array}$ & $\begin{array}{l}\varphi \\
\left({ }^{\circ}\right)\end{array}$ \\
\hline \multirow[t]{5}{*}{ I } & I 1 & 10,8 & 16,3 & & & & & 7,65 & 5,70 \\
\hline & I 3 & 10,4 & 15,8 & & & & & 7,72 & 9,91 \\
\hline & I 4 & 12,8 & 17,4 & \multirow{3}{*}{$1.10^{-3}$} & \multirow{3}{*}{$1.10^{-3}$} & \multirow{3}{*}{9807} & \multirow{3}{*}{0,30} & 8,0 & 17,97 \\
\hline & I 5 & 11,9 & 16,6 & & & & & 6,84 & 15,35 \\
\hline & I 8 & 12,8 & 16,8 & & & & & 9,13 & 19,25 \\
\hline \multirow[t]{6}{*}{ II } & II A1 & & & & & & & & 5,70 \\
\hline & II A2 & 10,4 & 15,8 & $1.10^{-3}$ & $1.10^{-3}$ & 9807 & 0,30 & 7,66 & 15,44 \\
\hline & II A3 & & & & & & & & 19,25 \\
\hline & II B1 & & & & & & & 4,10 & \\
\hline & II B2 & & & & & & & 7,66 & 15,44 \\
\hline & II B3 & 10,4 & 15,8 & $1.10^{-3}$ & $1.10^{-3}$ & 9807 & 0,30 & 9,13 & \\
\hline \multirow[t]{6}{*}{ III } & III A1 & & & & & & & & 5,70 \\
\hline & III A2 & 12,02 & 16,66 & $1.10^{-3}$ & $1.10^{-3}$ & 9807 & 0,30 & 7,66 & 15,44 \\
\hline & III A3 & & & & & & & & 19,25 \\
\hline & III B1 & & & & & & & 4,10 & \\
\hline & III B2 & 12,02 & 16,66 & $1.10^{-3}$ & $1.10^{-3}$ & 9807 & 0,30 & 7,66 & 15,44 \\
\hline & III B3 & & & & & & & 9,13 & \\
\hline
\end{tabular}

(Sumber : PPK Batas Jatim-Giriwoyo-Duwet. 2017)

\section{HASIL DAN PEMBAHASAN}

\section{Karakteristik Tanah}

a. Batas - Batas Atterberg dan Kadar Air

Hasil identifikasi tanah hasil uji batas-batas konsistensi (Atterberg Limits) pada 10 sampel tanah yang ada didapat rata-rata nilai batas cair ( $L L$ ) $72,97 \%$ dan nilai batas plastis (PL) $22,82 \% \quad$ serta nilai indeks plastisitas $(P I) \quad 50,16 \%$ dengan kadar air 73,42\%.

b. Gradasi Butiran

Hasil klasifikasi tanah berdasarkan grain size analysis dari 10 data bore log tanah pada proyek ini menunjukkan tanah jenis tanah silt loam (lanau berlumpur) dan silt (lanau) seperti yang dapat dilihat pada Gambar 4 dan Gambar 5.

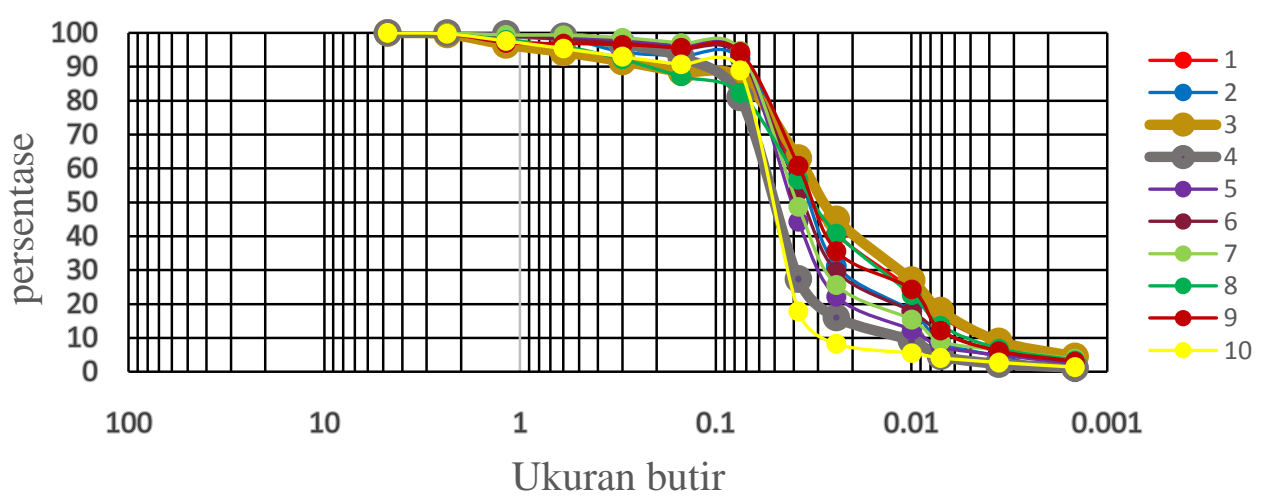

Gambar 4. Gradasi Analisa Butiran 


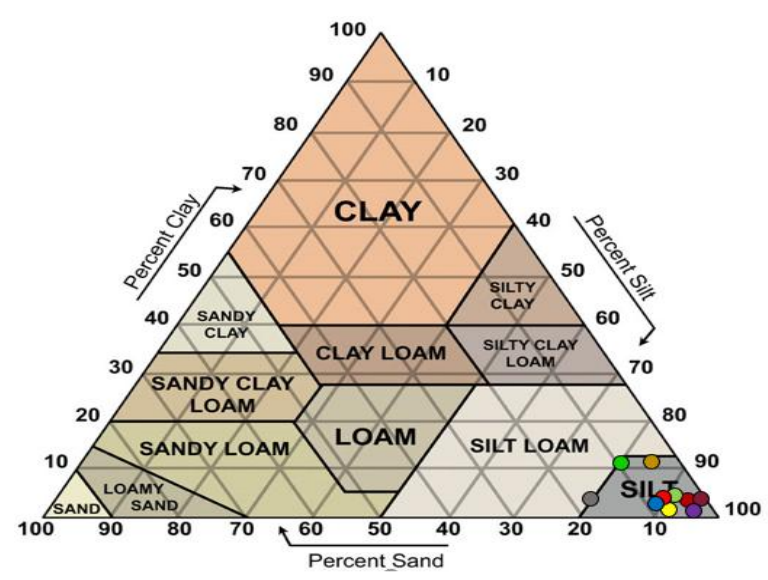

\begin{tabular}{|c|c|c}
\hline 1 & $\bullet$ & Silt \\
\hline 2 & $\bullet$ & Silt \\
\hline 3 & 0 & Silt \\
\hline 4 & 0 & Silt Loam \\
\hline 5 & $\bullet$ & Silt \\
\hline 6 & $\bullet$ & Silt \\
\hline 7 & $\circ$ & Silt \\
\hline 8 & $\bullet$ & Silt Loam \\
\hline 9 & $\bullet$ & Silt \\
\hline 10 & 0 & Silt \\
\hline
\end{tabular}

Gambar 5. Klasifikasi Jenis Tanah USDA

Tanah dengan karakteristik silt (lanau) pada umumnya tersusun atas kombinasi dari komponen pasir (020) \%, lanau (90-100)\% dan lempung (0-10)\%. Sementara itu tanah dengan karakteristik silt loam (lanau berlumpur) pada umumnya tersusun atas kombinasi dari komponen pasir (0-50)\%, lanau (71$100) \%$ dan lempung (0-29)\%.

c. Compaction Test

Dari hasil compaction test didapat nilai rata-rata CBR sebesar $4,28 \%$ dan nilai qu sebesar $0,256 \mathrm{Kg} / \mathrm{cm}^{2}$.

\section{d. Direct Shear Test}

Dari hasil direct Shear test didapat nilai rata-rata sudut geser sebesar $15,44^{\circ}$ dan angka kohesi rata-rata sebesar 7,66 KN/m².

\section{Hasil Analisis Perhitungan Besar Penurunan}

Hasil perhitungan penurunan dilakukan perbandingan tiga metode pada sampel tanah uji I3 atau pada STA 3+795 dengan menggunakan metode perhitungan plaxis, teoritis dan observasi lokasi dan di dapat hasil perbandingan selisih antara analisa plaxis dengan teoritis sebesar $0,674 \mathrm{~cm}$ dan plaxis dengan observasi lokasi terjadi selisih sebesar $1,896 \mathrm{~cm}$ seperti yang ditunjukkan pada Gambar 6.

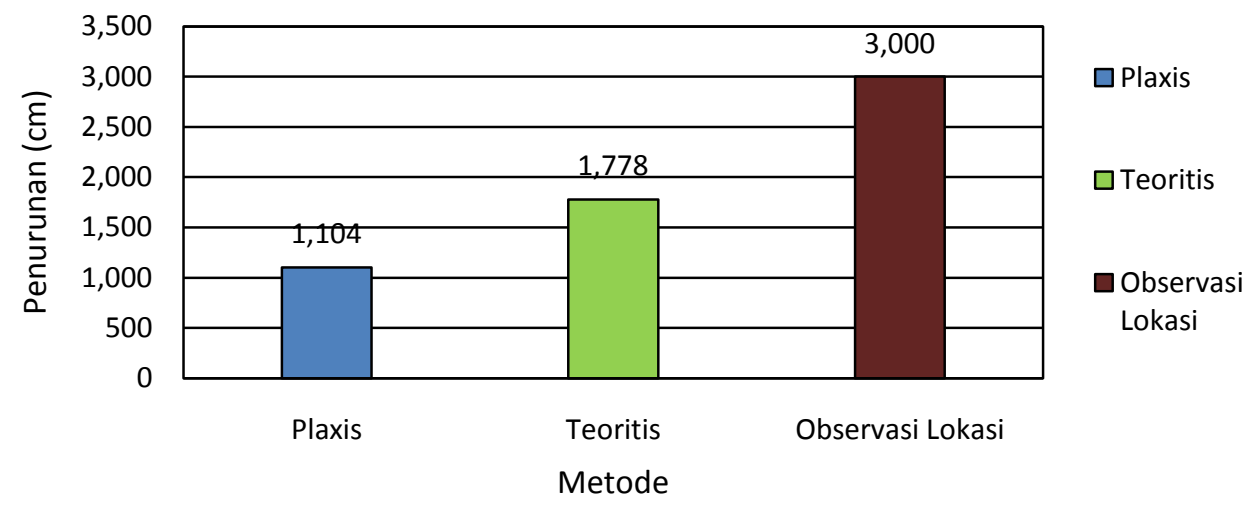

Gambar 6. Analisa Besar Penurunan 
Analisa plaxis dilakukan dengan tiga skenario dan dua permodelan yaitu tanpa geotekstile dan dengan geotekstile. Analisa tanpa geotekstile menunjukkan pada skenario satu terjadi penurunan terbesar yaitu 1,238 $\mathrm{cm}$ pada kasus I 1 yaitu tanah dengan nilai sudut geser lebih rendah dari kohesi yaitu $5,70^{\circ}$, nilai sudut geser pada parameter kasus ini adalah sudut geser terendah pada skenario 1. Nilai penurunan terbesar juga terjadi pada tanah dengan nilai sudut geser terkecil pada skenario dua dan skenario tiga. Hasil penurunan terkecil terjadi pada kasus tanah dengan parameter nilai kohesi terkecil, seperti pada kasus II B1 pada skenario dua terjadi penurunan sebesar $1,096 \mathrm{~cm}$ dengan nilai kohesi $4,10 \mathrm{KN} / \mathrm{m}^{2}$. Nilai penurunan terkecil terjadi pada kasus tanah dengan parameter kohesi terkecil pada skenario satu dan skenario tiga, seperti yang ditunjukkan pada Gambar 7.

Analisa dengan geotekstile menunjukkan pada skenario satu terjadi penurunan terbesar yaitu 1,247 $\mathrm{cm}$ pada kasus I 1 yaitu tanah dengan nilai sudut geser lebih rendah dari kohesi yaitu $5,70^{\circ}$, nilai sudut geser pada parameter kasus ini adalah sudut geser terendah pada skenario satu. Nilai penurunan terkecil pada setiap skenario terjadi pada kasus tanah dengan parameter sudut geser yang tinggi. Hasil analisa skenario satu menunjukkan tanah pada kasus I 4 dengan nilai sudut geser $17,97^{\circ}$ mengalami penurunan sebesar 1,075 $\mathrm{cm}$. Hasil analisa skenario dua menunjukkan tanah pada kasus II B3 dengan nilai sudut geser $15,44^{\circ}$ mengalami penurunan sebesar 1,058 $\mathrm{cm}$ dan hasil analisa skenario tiga menunjukkan tanah pada kasus III A3 dengan nilai sudut geser $19,25^{\circ}$ mengalami penurunan sebesar 1,066 $\mathrm{cm}$ seperti yang ditunjukkan pada Gambar 8.

$\begin{array}{ccc}\text { Hasil analisa } & \text { gabungan } \\ \text { menunjukkan } & \text { beberapa } & \text { perilaku }\end{array}$ penurunan tanah akibat penambahan geotekstile. Penambahan geotekstile sangat berpengaruh mengurangi penurunan pada kasus tanah dengan parameter nilai sudut geser lebih kecil dari nilai kohesi, seperti pada kasus II A1 pada skenario dua yang mengalami perbedaan penurunan tanah sebesar 0,076 $\mathrm{cm}$ dan pada skenario tiga kasus III A1 mengalami perbedaan penurunan sebesar $0,097 \mathrm{~cm}$, seperti yang ditunjukkan pada Gambar 9. Analisa menunjukkan terjadi pergerakan penurunan tanah yang sangat signifikan akibat beban kendaraan, seperti yang ditunjukkan pada Gambar 10. 


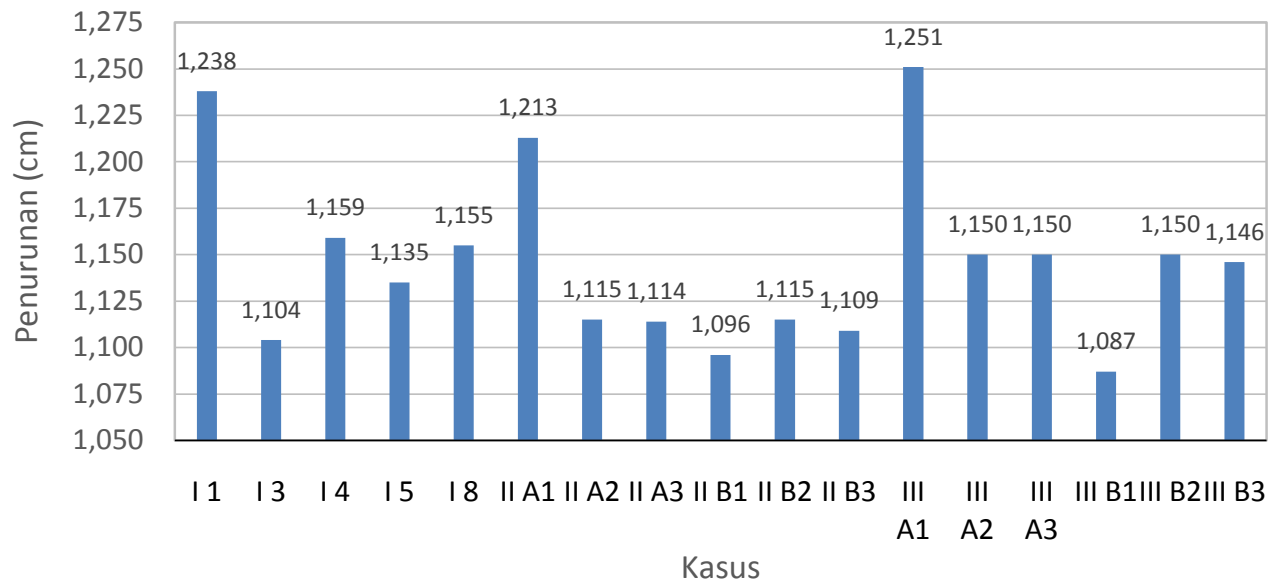

Gambar 7. Analisa Plaxis Tanpa Geotekstile

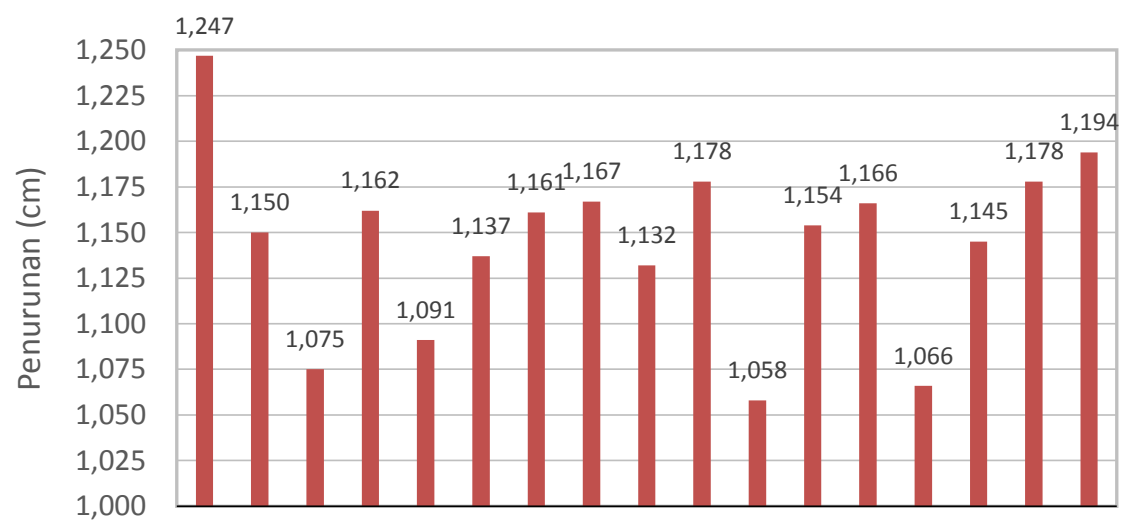

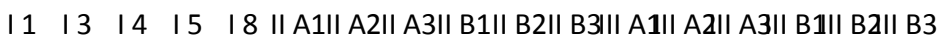
Kasus

Gambar 8. Analisa Plaxis Dengan Geotekstile

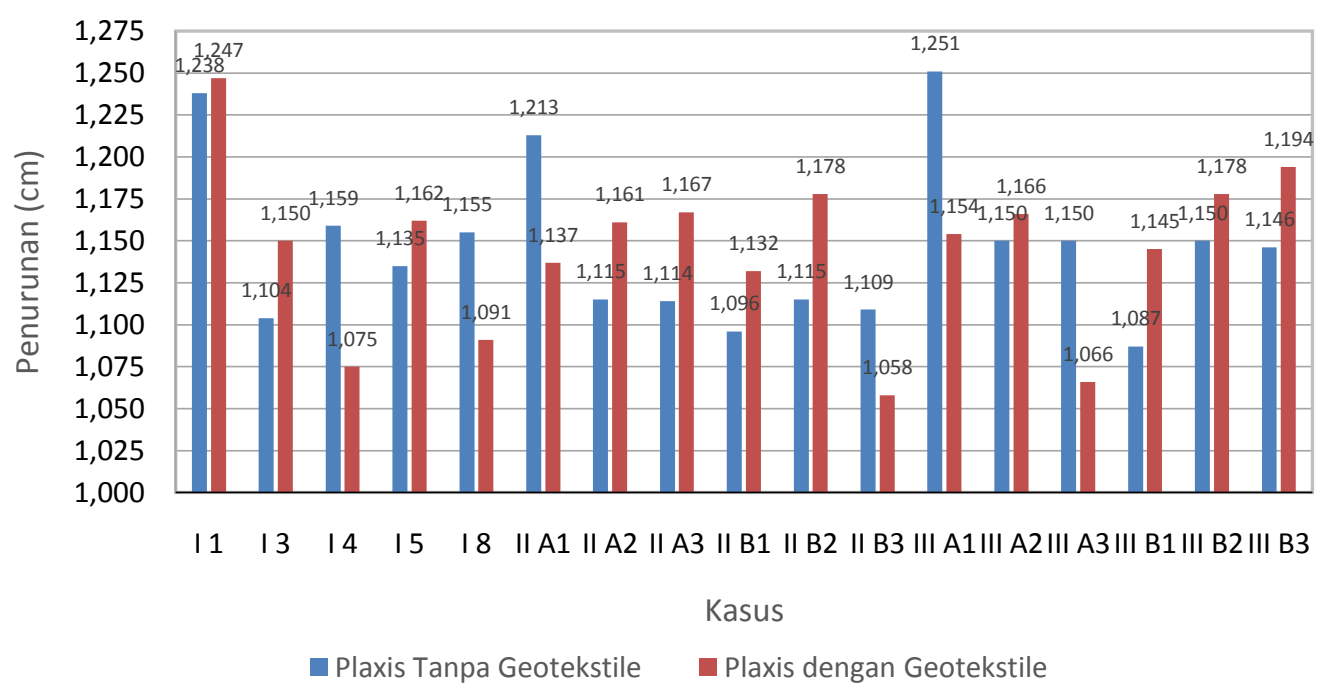

Gambar 9. Analisa Plaxis Gabungan 


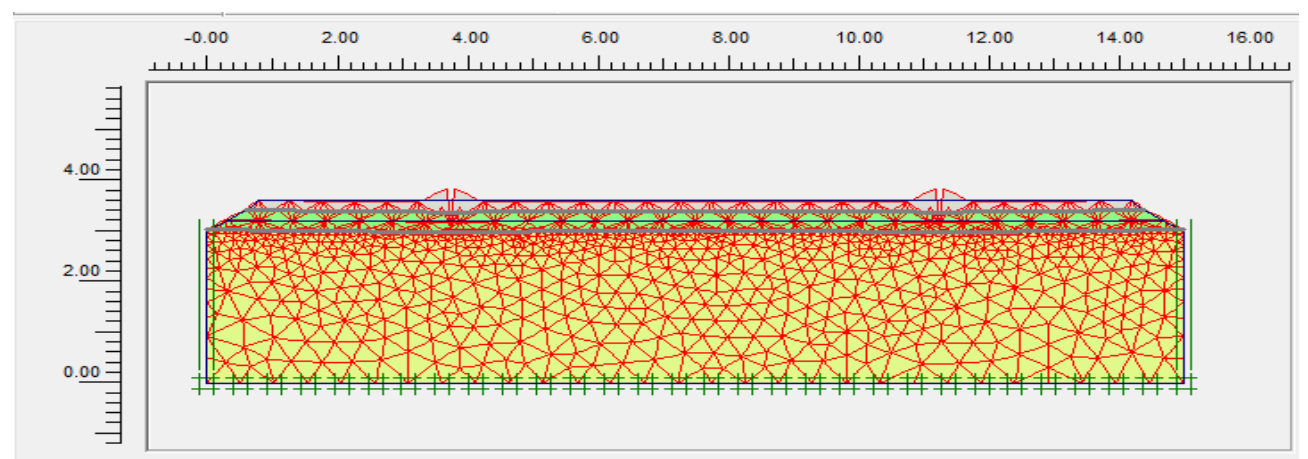

Gambar 10. Extreme Total Displacement

\section{SIMPULAN}

Berdasarkan data profil tanah proyek pembangunan jalan nasional ruas Giriwoyo-Duwet, Wonogiri, Jawa Tengah. Tanah pada proyek tersebut mempunyai karakteristik nilai batas cair $(L L) 72,97 \%$, nilai batas plastis $(P L)$ 22,82\%, nilai indeks plastisitas (PI) 50,16\%, kadar air $73,42 \%$, nilai rata-rata CBR sebesar $4,28 \%$, nilai qu sebesar $0,256 \mathrm{Kg} / \mathrm{cm}^{2}$, dan berdasarkan analisa USDA merupakan tanah berjenis silt atau lanau.

Terjadinya penurunan pada tanah timbunan proyek pembangunan jalan nasional ruas Giriwoyo-Duwet, Wonogiri, Jawa Tengah disebabkan karena karakteristik tanah yang merupakan jenis tanah lunak dan berplastisitas tinggi sehingga tanah mudah mengalami kembang susut dan penurunan ketika terkena beban. Tanah timbunan yang digunakan juga merupakan jenis tanah silt atau lanau, tanah jenis ini merupakan jenis tanah yang tidak direkomendasikan sebagai tanah timbunan.

Hasil analisis besar penurunan dengan metode plaxis di dapat nilai penurunan sebesar $1,104 \mathrm{~cm}$, metode teoritis $1,896 \mathrm{~cm}$ dan hasil observasi langsung sebesar $3 \mathrm{~cm}$. Hasil analisis menunjukkan perbandingan selisih antara analisa plaxis dengan teoritis sebesar 0,674 $\mathrm{cm}$ dan plaxis dengan observasi lokasi terjadi selisih sebesar $1,896 \mathrm{~cm}$.

\section{DAFTAR PUSTAKA}

Aridini, L.K., 2017, Pengaruh Beban Tanah Timbunan Terhadap Daya Dukung Pondasi Rakit Menggunakan Program Plaxis, Tugas Akhir, Lampung, Jurusan Teknik Sipil Universitas Lampung

Budi, G.S., Susanto, H., Condro, S.R., 2003, Evaluasi Penurunan Tanah Liat Dengan Metode Sub-Layer, Jurnal Civil Engineering Dimension, Volume 5. Nomor 1. Halaman 14-19

Daryaei, R. dan Eslami, A., 2017, Settlement Evaluation of Explosive Compaction in

Saturated Sands. Jurnal Soil Dinamics and Earthquake Engineering. Volume 97. Halaman 241-250

Fandisnata, S., 2014, Studi Perbandingan Kapasitas Dukung Embankment dengan Perkuatan Geotextile, Cerucuk Tegak dan Cerucuk Miring Kayu Galam. 
Tugas Akhir, Makassar, Jurusan

Teknik Sipil Universitas

Hasanuddin

Nawir, H., Apoji, D., Fatimatuzahro, R., Pamudji, M.D., 2012, Prediksi Penurunan Tanah Menggunakan Prosedur

Observasi Asaoka Studi Kasus: Timbunan di Bontang, Kalimantan Timur, Jurnal Teoretis dan Terapan Bidang Rekayasa Sipil, Vol 19. Nomor 2. Halaman 133-148

Pasaribu, T.H. dan Iskandar, R., 2012, Analisa Penurunan Pada Tanah Lunak Akibat Timbunan (Studi Kasus Runway Bandara Medan Baru), Tugas Akhir, Medan, Jurusan Teknik Sipil Universitas Sumatra Utara

Pejabat Pembuat Komitmen Batas Jatim-Giriwoyo-Duwet, 2015, Informasi Kegiatan PPK Batas Jatim-Giriwoyo-Duwet
Pejabat Pembuat Komitmen Batas Jatim-Giriwoyo-Duwet, 2017, Informasi Kegiatan PPK Batas Jatim-Giriwoyo-Duwet

Plaxis, 2007, Plaxis Version 8 Tutorial Manual

Terzaghi, K. 1943. Theoretical Soil Mechanics : Wiley and Sons

Widianti, A., 2012, "Pengaruh Jumlah Lapisan dan Spasi Perkuatan Geosintektik Terhadap Kuat Dukung dan Penurunan Tanah Lempung Lunak", Jurnal Semesta Teknika, Volume 15. Nomor 1. Halaman 90-97

Zahara, S., 2008, Kontrol Penurunan Tanah Akibat Timbunan pada Titik dengan Bore Log Test No. BH-II (Area-II) Proyek Bandar Udara Kuala Namu, Tugas Akhir, Medan, Jurusan Teknik Sipil Universitas Sumatera Utara 